Authors' Contribution: A Study Design B Data Collection C Statistical Analysis D Data Interpretation

E Manuscript Preparation F Literature Search G Funds Collection

\section{Body build of 14-16-year-old boys practising football and basketball as compared with non-training peers}

\author{
Monika Opanowska ${ }^{1 \text { ABCDEf }}$, Elżbieta Prętkiewicz-Abacjew² ADEF, \\ Paweł Skonieczny ${ }^{1} \mathrm{CD}$ \\ ${ }^{1}$ Gdansk University of Physical Education and Sport in Gdansk, Poland \\ 2 Faculty of Physiotherapy and Health Science, Management College in Gdansk, Poland
}

\section{abstract}

Background

Material/Methods

Results

Conclusions

Key words
The purpose of the study was to compare the somatic build of football and basketball players aged 14, 15 and 16 years with non-training boys of the same age.

The study involved 301 boys, who were divided into three study groups: football players, basketball players and non-training boys. The level of the boys' somatic development was established on the basis of body weight and height measurements, which were the basis for determining the BMI and Rohrer's index. In addition, the functional lengths of the right and the left lower extremity were studied.

The majority of training and non-training boys were characterised by the leptosomatic body type. Basketball players across study groups were statistically significantly taller and heavier in comparison to non-training boys. Only the body weight between16-year-old basketball players and non-training boys was statistically insignificantly different. Only 14-year-old footballers were statistically significantly taller and had longer lower limbs as compared with their non-training peers.

In view of the sporadic lack of differences between football players and non-training boys, the analysed biometric features of the body build, i.e. body weight and height, should not be treated as the only criterion for selection to play football, while in the case of basketball players a possibility of using these data should be taken into consideration, with additional focus on the length of lower limbs.

body build, football players, basketball players, sports training

\section{article details}

Article statistics

Full-text PDF:

Copyright

Indexation:

Funding:

Conflict of interest: Corresponding author:

Open Access License:
Word count: 2,894; Tables: 4; Figures: 0; References: 36

Received: January 2016; Accepted: December 2016; Published: March 2017

http://www.balticsportscience.com

(c) Gdansk University of Physical Education and Sport, Poland

AGRO, Celdes, CNKI Scholar (China National Knowledge Infrastructure), CNPIEC, De Gruyter - IBR (International Bibliography of Reviews of Scholarly Literature in the Humanities and Social Sciences), De Gruyter - IBZ (International Bibliography of Periodical Literature in the Humanities and Social Sciences), DOA), EBSCO - Central $\&$ Eastern European Academic Source, EBSCO - SPORTDiscus, EBSCO Discovery Service, Google Scholar, Index Copernicus, J-Gate, Naviga (Softweco, Primo Central (ExLibris), ProQuest - Family Health, ProQuest - Health \& Medical Complete, ProQuest - Illustrata: Health Sciences, ProQuest - Nursing \& Allied Health Source, Summon (Serials Solutions/ProQuest, TDOne (TDNet), Ulrich's Periodicals Directory/ulrichsweb, WorldCat (OCLC)

\section{sectors.}

Authors have declared that no competing interest exists.

Dr. Monika Opanowska, Gdansk University of Physical Education and Sport, ul. Kazimierza Gorskiego 1, 80-336 Gdansk, Poland Phone number: 585547266, e-mail: monkao84@wp.pl

This is an open access article distributed under the terms of the Creative Commons Attribution-Non-commercial 4.0 International (http://creativecommons.org/licenses/by-nc/4.0/), which permits use, distribution, and reproduction in any medium, provided the original work is properly cited, the use is non-commercial and is otherwise in compliance with the license. 


\section{INTRODUCTION}

Physical activity is one of the exogenous factors which have a positive influence on the biological development of children and youth [1, 2]. Focused, organized and rationally applied movement is beneficial to the body and boosts the growth of the musculoskeletal system; on the other hand, too-early initiated sports training, too heavy physical burden and monotypic movement and strain may negatively affect a developing body [3]. One of the negative results may be growth obstruction and an asymmetry in body proportions. The direction and development speed of physical fitness as well as specific morphofunctional characteristics, including body build, will depend on the type of sport practised $[2,3]$.

The aim of the research was to compare the somatic build of football players and basketball players vs. a group of non-training boys at or around puberty age, i.e. 14-, 15- and 16-year-olds.

\section{MATERIALS AND METHOD}

The research was carried out at the Laboratory of Posturology and Corrective Exercises Methodology at the University of Physical Education and Sport in Gdansk in the school year 2009/2010 and 2010/2011 in a population of 301 boys, students of junior secondary schools in Tri-City (Gdansk-Gdynia-Sopot, Poland).

The study involved boys practising sport and non-practising boys aged 14-16 years. The subjects' calendar age was established using the method described by Wolanski [4]; as a result, age units were identified, i.e. 14-year-olds, 15-yearolds, and 16-year-olds. Within each unit boys were divided into 3 study groups. The main inclusion criterion for a group was the type of team sport practised: the 1 st study group - football players (108 subjects), the 2nd study group basketball players (92 subjects), and the 3rd study group (control group) - nontraining boys (101 subjects). The athlete groups were made up of boys belonging to sports clubs situated in the Tri-City agglomeration. The non-training group consisted of pupils who until the time of the study had not taken part in sports training but took part in Physical Education lessons at school to the extent specified in the curriculum. The inclusion criterion for the footballers' or the basketball players' group was having trained their team sport for over 4 years and not having practised any other sport until the time of and during the study. Training boys were sampled using the purposive quota sampling method, whereas non-training ones were sampled using random group sampling [5]. The characteristics of each of the study groups are shown in Tables 1-2.

Table 1. Numerical characteristics of the study groups including calendar age

\begin{tabular}{|c|c|c|c|c|c|c|c|c|}
\hline \multirow{3}{*}{ Study group } & \multicolumn{6}{|c|}{ Age (years) } & \multirow{2}{*}{\multicolumn{2}{|c|}{ Total }} \\
\hline & \multicolumn{2}{|c|}{14} & \multicolumn{2}{|c|}{15} & \multicolumn{2}{|c|}{16} & & \\
\hline & $\mathrm{n}$ & $\%$ & $\mathrm{n}$ & $\%$ & $\mathrm{n}$ & $\%$ & $\mathrm{~N}$ & $\%$ \\
\hline Football players & 28 & 25.9 & 43 & 39.9 & 37 & 34.2 & 108 & 100.0 \\
\hline Basketball players & 21 & 22.8 & 48 & 52.2 & 23 & 25.0 & 92 & 100.0 \\
\hline Non-training & 36 & 35.6 & 29 & 28.7 & 36 & 35.7 & 101 & 100.0 \\
\hline
\end{tabular}


Table 2. Study groups characteristics by training experience, number of practice sessions/ $\mathrm{PE}$ lessons at school and the duration of one practice unit/PE lesson

\begin{tabular}{|c|c|c|c|c|c|c|c|c|c|c|}
\hline \multicolumn{2}{|c|}{ Training characteristics } & \multicolumn{3}{|c|}{ Football players (age in years) } & \multicolumn{3}{|c|}{ Basketball players (age in years) } & \multicolumn{3}{|c|}{ Non-training (age in years) } \\
\hline & & 14 & 15 & 16 & 14 & 15 & 16 & 14 & 15 & 16 \\
\hline \multirow{2}{*}{$\begin{array}{l}\text { Training } \\
\text { experience } \\
\text { (years) }\end{array}$} & $\bar{x} \pm S$ & $5.34 \pm 1.1$ & $6.64 \pm 1.5$ & $7.40 \pm 1.7$ & $4.71 \pm 0.8$ & $4.82 \pm 0.7$ & $5.17 \pm 1.4$ & ---- & ---- & ---- \\
\hline & $\operatorname{Min} \div \operatorname{Max}$ & $4.0 \div 8.0$ & $4.0 \div 11.0$ & $4.0 \div 11.5$ & $4.0 \div 7.0$ & $4.0 \div 7.0$ & $4.0 \div 9.0$ & ---- & ----- & ---- \\
\hline \multirow{2}{*}{$\begin{array}{l}\text { Number of } \\
\text { trainings } \\
\text { weekly (n) }\end{array}$} & $\bar{x} \pm S$ & $4.00 \pm 0.0$ & $4.42 \pm 0.6$ & $5.24 \pm 0.8$ & $5.47 \pm 1.5$ & $3.85 \pm 1.2$ & $6.13 \pm 2.7$ & ---- & ----- & ---- \\
\hline & $\operatorname{Min} \div \operatorname{Max}$ & $4.0 \div 4.0$ & $4.0 \div 6.0$ & $4.0 \div 6.0$ & $4.0 \div 7.0$ & $4.0 \div 7.0$ & $2.0 \div 10.0$ & ---- & ----- & ---- \\
\hline \multirow{2}{*}{$\begin{array}{l}\text { Duration of } \\
\text { one practice } \\
\text { (mins) }\end{array}$} & $\bar{x} \pm S$ & $90.00 \pm 0.0$ & $90.00 \pm 0.0$ & $90.00 \pm 0.0$ & $90.00 \pm 0.0$ & $94.20 \pm 30.0$ & $153.60 \pm 96.0$ & ---- & ----- & ---- \\
\hline & $\operatorname{Min} \div \operatorname{Max}$ & $90.0 \div 90.0$ & $90.0 \div 90.0$ & $90.0 \div 90.0$ & $90.0 \div 90.0$ & $90.0 \div 300.0$ & $90.0 \div 300.0$ & ---- & ----- & ---- \\
\hline \multirow{2}{*}{$\begin{array}{l}\text { No. of PE } \\
\text { lessons at } \\
\text { school } \\
\text { weekly (n) }\end{array}$} & $\bar{x} \pm S$ & $0.79 \pm 0.4$ & $0.40 \pm 0.5$ & $0.67 \pm 0.4$ & $0.66 \pm 0.9$ & $1.60 \pm 1.2$ & $0.43 \pm 1.0$ & $3.58 \pm 0.5$ & $3.17 \pm 0.3$ & $3.02 \pm 0.1$ \\
\hline & $\operatorname{Min} \div \operatorname{Max}$ & $0.0 \div 1.0$ & $0.0 \div 1.0$ & $0.0 \div 1.0$ & $0.0 \div 4.0$ & $0.0 \div 4.0$ & $0.0 \div 4.0$ & $3.0 \div 4.0$ & $3.0 \div 4.0$ & $3.0 \div 4.0$ \\
\hline \multirow{2}{*}{$\begin{array}{l}\text { Duration of } \\
\text { PE lessons } \\
\text { at school } \\
\text { weekly } \\
\text { (mins) }\end{array}$} & $\bar{x} \pm S$ & $71.37 \pm 37.1$ & $32.14 \pm 41.3$ & $40.13 \pm 33.1$ & $38.57 \pm 43.3$ & $61.87 \pm 31.6$ & $15.65 \pm 32.1$ & $45.00 \pm 0.00$ & $45.00 \pm 0.00$ & $45.00 \pm 0.00$ \\
\hline & $\operatorname{Min} \div \operatorname{Max}$ & $0.0 \div 90.0$ & $0.0 \div 90.0$ & $0.0 \div 90.0$ & $0.00 \div 45.0$ & $0.0 \div 90.0$ & $0.0 \div 90.0$ & $45.0 \div 45.0$ & $45.0 \div 45.0$ & $45.0 \div 45.0$ \\
\hline
\end{tabular}

The boys' somatic development was established on the basis of body weight and height measurements according to anthropometric rules [6]. The body height was measured standing, using the height measuring tool - PORTSTAND 210 Stadiometer with $1 \mathrm{~mm}$ accuracy, while the body mass was measured using medical electronic scales with $100 \mathrm{~g}$ accuracy. Based on the results of height and weight measurements, the subjects' body mass index (BMI) and Rohrer's index were calculated.

On the basis of Rohrer's index, using the formula given by Curtius [7] and Kretschmer's typology, three constitutional body build types were established:

$\leq 1.27$ - the leptosomatic type

1.27-1.49 - the athletic type

$\geq 1.50$ - the pyknic type

In addition, the relative (functional) lengths of the right and the left lower limbs were examined. The relative length of the lower limbs involved measurement from the anterior-superior iliac spine to the medial malleolus of the shin, which was taken in the supine lying position with straightened lower limbs [8]. The length was measured with a measuring tape, with $1 \mathrm{~mm}$ accuracy.

The obtained data were then processed in statistical analysis based on STATISTICA 10 statistics software and a Microsoft Excel spreadsheet [9]. The key numeric characteristics were calculated: the mean value and the standard deviation as well as the minimum and maximum values and the coefficient of variation. In order to determine the significance of differences between groups, a variance analysis tool was used - comparisons planned with the contrast approach. The assumed statistical significance alpha $=0.05$. 


\section{RESULTS}

Numeric data of the analysed somatic development characteristics of football players, basketball players and non-training boys are shown in Table 3.

Table 3. Numeric characteristics of variables: body weight, body height, BMI, Rohrer's index, and relative lower limb length in the study groups

\begin{tabular}{|c|c|c|c|c|c|c|c|c|}
\hline \multirow{2}{*}{$\begin{array}{c}\text { Somatic } \\
\text { characteristic }\end{array}$} & \multirow{2}{*}{$\begin{array}{c}\text { Age } \\
\text { [years] }\end{array}$} & \multicolumn{2}{|c|}{ Football players (F) } & \multicolumn{2}{|c|}{ Basketball players (B) } & \multicolumn{2}{|c|}{ Non-training (NT) } & \multirow{2}{*}{$P$} \\
\hline & & $\bar{x} \pm \mathrm{SD}$ & $\begin{array}{c}\mathrm{V} \\
{[\%]}\end{array}$ & $\bar{x} \pm \mathrm{SD}$ & $\begin{array}{c}\mathrm{V} \\
{[\%]}\end{array}$ & $\bar{x} \pm \mathrm{SD}$ & $\begin{array}{c}\mathrm{V} \\
{[\%]}\end{array}$ & \\
\hline \multirow{3}{*}{ Body weight (kg) } & 14 & $58.56 \pm 10.37$ & 17.7 & $63.35 \pm 14.17$ & 22.4 & $55.46 \pm 12.94$ & 23.3 & NT vs. B* \\
\hline & 15 & $62.86 \pm 8.31$ & 13.2 & $69.32 \pm 11.50$ & 16.6 & $62.00 \pm 11.63$ & 18.8 & NT vs. B** \\
\hline & 16 & $66.25 \pm 8.64$ & 13.0 & $72.47 \pm 9.52$ & 13.1 & $69.48 \pm 14.31$ & 20.6 & ------- \\
\hline \multirow{3}{*}{ Body height (cm) } & 14 & $170.48 \pm 8.28$ & 4.9 & $174.88 \pm 9.17$ & 5.2 & $164.7 \pm 9.28$ & 5.6 & $\begin{array}{c}\text { NT vs. } \mathrm{F}^{* *} \text { and } \\
\mathrm{B}^{* * *}\end{array}$ \\
\hline & 15 & $174.36 \pm 5.66$ & 3.2 & $180.18 \pm 7.28$ & 4.0 & $171.12 \pm 7.62$ & 4.5 & NT vs. $B^{* * *}$ \\
\hline & 16 & $175.32 \pm 6.54$ & 3.7 & $184.09 \pm 7.57$ & 4.1 & $176.53 \pm 6.87$ & 3.9 & NT vs. $B^{* * *}$ \\
\hline \multirow{3}{*}{ BMI $\left(\mathrm{kg} / \mathrm{m}^{2}\right)$} & 14 & $20.02 \pm 2.60$ & 13.0 & $20.53 \pm 3.07$ & 14.9 & $20.24 \pm 3.28$ & 16.2 & ------- \\
\hline & 15 & $20.62 \pm 2.04$ & 9.9 & $21.27 \pm 2.67$ & 12.6 & $21.11 \pm 3.49$ & 16.5 & ------- \\
\hline & 16 & $21.49 \pm 2.03$ & 9.5 & $21.35 \pm 2.23$ & 10.4 & $22.22 \pm 4.02$ & 18.1 & ------- \\
\hline \multirow{3}{*}{$\begin{array}{l}\text { Rohrer's index } \\
\left(\mathrm{g} / \mathrm{cm}^{3}\right)\end{array}$} & 14 & $1.17 \pm 0.14$ & 12.2 & $1.17 \pm 0.16$ & 13.4 & $1.23 \pm 0.18$ & 15.0 & -------- \\
\hline & 15 & $1.18 \pm 0.11$ & 9.7 & $1.18 \pm 0.15$ & 12.3 & $1.24 \pm 0.21$ & 17.0 & ------- \\
\hline & 16 & $1.23 \pm 0.12$ & 9.4 & $1.16 \pm 0.13$ & 11.2 & $1.26 \pm 0.23$ & 17.9 & NT vs. B* \\
\hline \multirow{3}{*}{$\begin{array}{l}\text { Length of the left } \\
\text { lower } \operatorname{limb}(\mathrm{cm})\end{array}$} & 14 & $91.05 \pm 5.23$ & 5.7 & $93.14 \pm 6.03$ & 6.5 & $88.04 \pm 5.28$ & 6.0 & NT vs. $\mathrm{F}^{* *}$ and $\mathrm{B}^{* *}$ \\
\hline & 15 & $92.97 \pm 3.65$ & 3.9 & $96.51 \pm 5.62$ & 5.8 & $92.19 \pm 4.92$ & 5.3 & NT vs. B*** \\
\hline & 16 & $93.37 \pm 4.58$ & 4.9 & $99.07 \pm 5.61$ & 5.7 & $94.08 \pm 5.99$ & 6.4 & NT vs. B*** \\
\hline \multirow{3}{*}{$\begin{array}{l}\text { Length of the } \\
\text { right lower limb } \\
\text { (cm) }\end{array}$} & 14 & $91.05 \pm 5.23$ & 5.7 & $93.14 \pm 6.12$ & 6.6 & $88.05 \pm 5.26$ & 6.0 & NT vs. $\mathrm{F}^{*}$ and $\mathrm{B}^{* * *}$ \\
\hline & 15 & $92.94 \pm 3.67$ & 4.0 & $96.52 \pm 5.62$ & 5.8 & $92.17 \pm 4.91$ & 5.3 & NT vs. B*** \\
\hline & 16 & $93.35 \pm 4.66$ & 5.0 & $99.07 \pm 5.61$ & 5.7 & $94.07 \pm 6.03$ & 6.4 & NT vs. B*** \\
\hline
\end{tabular}

*) $p<0.05, \quad * *) p<0.01, \quad * * *) p<0.001$

F - football players, B - basketball players, NT - non-training

Football players aged 14 and 15 years were taller and heavier that their nontraining peers, whereas football players aged 16 years showed lower mean values of the body weight and height as compared to non-training boys. A statistically significant difference $(p<0.01)$ was only found in the body height between 14-year-old football players and their non-training peers.

Basketball players across study groups were statistically significantly taller $(p<0.001)$ and heavier $(p<0.05$ and $p<0.01)$ in comparison to their nontraining peers. Only the 16-year-old group did not differ in a statistically significant way with respect to their body weight.

The mean body mass index (BMI) values in particular age groups were not statistically significantly different. Both in the training and non-training boys, the body mass index increased with age. 
The mean value of Rohrer's index in the discussed study groups was characteristic of the leptosomatic body build and did not show statistically significant differences between the study groups except the lower and statistically significant $(p<0.05)$ mean value in 16 -year-old basketball players as compared to their non-training peers. Across all age groups of both the training and non-training boys, the leptosomatic body type dominated; the athletic type was less frequent and the pyknic type, mostly found in the nontraining group, was in the minority (Tab. 4). Due to a modest number of the somatic types in some age (fewer than 5 boys), an analysis of their occurrence was abandoned since formulating conclusions in such cases is unjustified.

Table 4. Occurrence of body types in football players, basketball players and non-training boys

\begin{tabular}{|c|c|c|c|c|c|c|c|}
\hline \multirow{2}{*}{$\begin{array}{c}\text { Age } \\
\text { [years] }\end{array}$} & \multirow{2}{*}{ Body build type } & \multicolumn{2}{|c|}{ Football players } & \multicolumn{2}{|c|}{ Basketball players } & \multicolumn{2}{|c|}{ Non-training } \\
\hline & & $\mathrm{n}$ & $\%$ & $\mathrm{n}$ & $\%$ & $\mathrm{n}$ & $\%$ \\
\hline \multirow{3}{*}{14} & leptosomatic & 22 & 20.40 & 17 & 18.48 & 24 & 23.52 \\
\hline & athletic & 5 & 4.62 & 3 & 3.26 & 10 & 9.80 \\
\hline & pyknic & 1 & 0.92 & 1 & 1.09 & 2 & 1.96 \\
\hline \multirow{3}{*}{15} & leptosomatic & 37 & 34.25 & 37 & 40.21 & 22 & 21.56 \\
\hline & athletic & 6 & 5.55 & 10 & 10.87 & 2 & 1.96 \\
\hline & pyknic & 0 & 0.00 & 1 & 1.09 & 5 & 4.90 \\
\hline \multirow{3}{*}{16} & leptosomatic & 25 & 23.14 & 19 & 20.65 & 22 & 21.56 \\
\hline & athletic & 11 & 10.20 & 4 & 4.35 & 8 & 7.84 \\
\hline & pyknic & 1 & 0.92 & 0 & 0.00 & 6 & 5.90 \\
\hline
\end{tabular}

The highest mean vales of the functional lengths of the right and the left lower limbs were found in basketball players, and the lowest ones in nontraining boys. The differences in the right and the left lower limb lengths within groups were statistically insignificant. The study, on the other hand, showed statistically significant differences $(p<0.01$ and $p<0.001)$ between basketball players and non-training boys with respect to the relative length of the lower limbs (left and right), and between 14-year-old football players and their non-training peers $(p<0.05)$ also with respect to the functional lengths of the lower limbs (left and right).

\section{DISCUSSION}

Research whose results are presented in this paper confirms the problem discussed in literature, concerning the somatic build of training and nontraining persons [e.g. 10, 11, 12].

In own research, football players and basketball players aged 14-16 years were examined, and the obtained data were then compared with those of their nontraining peers. The study subjects were boys at or around puberty age, which is considered to be one of the most tumultuous stages in a young person's life, due to changes related to sexual maturation that the body undergoes. This period may lead to numerous disadvantageous changes in the movement, physical, psychological and intellectual spheres; therefore, young people should be given special care and supervision at that age. On the other hand, at puberty age in many sports, focused sports practice characterized by increased training 
load is carried out, which may affect the body build and posture, and through this, the level of physical fitness of a young person.

Results of own research and that by other authors found in available literature on the body build of football players and non-training boys at or around puberty, concerning the differentiation in body weight and height, are not fully consistent [e.g. 13, 14, 15, 16, 17]. It may be assumed that boys' body weight and height should not be the only choice criterion for football, and selection to take a particular position on the pitch in the preliminary and focused phase of a football player's training should rely on the assessment of the player's general fitness and his comprehensive technical and tactical skills.

Authors researching the above topic [e.g. 13, 14, 15, 16, 17] proved that football players' body weight and height were lower than in their non-training peers, similar to this research, and the differences were not statistically significant. Also, in Cieszczyk and Stepinski's research [18], conducted among 10-yearold boys who trained selected team sports, football players were shorter than basketball players, but when compared to volleyball players, handball players or non-training individuals, there was no statistically significant difference. Only 11-year-old football players achieved definitely lower body weight, statistically significantly different when compared with non-training peers [15].

The high average value of body weight in the case of basketball players was a natural consequence of their height, which was reflected in their BMI. It is worthwhile to stress here that, according to anthropologists' opinion [3, 12], high body weight in basketball players is by no means evidence of fat content in their bodies. Body weight assessed in this research was a general value and should be seen more with respect to the active mass (FFM) and passive or fat mass (FM); however, detailed assessment of body composition was not the purpose of this paper.

Similar research results with regard to body weight and height in 14-16-yearold Portuguese basketball players were obtained by Carvalho et al. [11, 19]. Research carried out by Litkowycz et al. [20] among basketball players and non-training boys in the following age groups: 13-15, 15-17, 17-18 years old, confirmed the results of this research that young people who train basketball are taller and heavier than non-training ones. Also, similar results were obtained by Hadzic et al. [21], Koley and Singh [22] and Popovic et al. [23] in studies of adult basketball players vs. physically non-active men. Litkowycz et al. [20] also proved that basketball players aged 13.5 years match non-training boys aged 17.5 years in body height. Czarny et al. [24] showed different results, proving that body weight and height of 10-19-yearold basketball players does not differ from nationwide Polish norms specified by the Institute of Mother and Child. Furthermore, Vamvakoudis et al. [25] showed in a long-term study (every 6 months from the age of 11.5 to 13.0) that boys' body weight was slightly greater than that of basketball players but did not differ in statistically significant way. Young basketball players in their research were, on the other hand, taller than non-training peers while a statistically significant difference only involved 12.5 -year-old boys. It can be assumed, in accordance with Konieczna's [16] opinion, that training burden which basketball players were exposed to could be the factor leading to accelerated - versus non-training people - increase in their height. 
Body height is important in basketball and often determines the ability to win, since a tall player has an advantage while fighting for ball possession, reaches the basket hoop more easily and collects the ball from the backboard [23, 26]. Differences in basketball players' body height may be observed depending on a player's position on the court. Centre players, who are mostly responsible for scoring from short shots and collecting the ball from the backboard, are taller than forwards and guards [27, 28, 29].

The length of lower limbs is a component of body height. In own research, a statistically significant difference in the functional lengths of the left and the right lower limbs was observed only between basketball players and nontraining boys across all the age groups in favour of basketball players, and between 14-year-old football players and non-training peers in favour of the footballers. Higher values of the relative lengths of lower limbs in basketball players were components of their overall body height. Litkowycz et al. [20] state that basketball players have longer lower limbs and torso because their body length is the key factor in technical actions during a game and is advantageous to success. The taller a player, or the longer a player's lower limbs, the higher the jumps which occur very frequently in a basketball game. As opposed to a basketball player, a model football player is characterized by short lower limbs and a short torso, which is related to a lower centre of gravity of his body [16]. This may be favourable to more dynamic moves, faster movement of the whole body and more accurate completion of technical actions.

Results related to the body mass index in boys in each particular group in this research are further confirmed in studies by other authors who focus on the somatic development of football players [30, 31], basketball players [32, 33, $34]$ as well as non-training boys $[35,36]$ at or around puberty.

The body build type of the boys in the three study groups as estimated from the viewpoint of slenderness-corpulence using Rohrer's index was in the lowest category of the index, which is characteristic of the leptosomatic type. The boys in the study were characterized by slender or frail body build with the length measurements exceeding the width measurements and with a flat chest [7]. It may be assumed that the boys' slender body build was a result of their young age and the sexual maturation they were undergoing, a time when, as stated by Januszewski and Mleczko [36], a decrease in Rohrer's index is normal. Furthermore, it can be noted that among non-training boys, the pyknic body type was found more frequently than among those who practised sport, possibly related to their high body weight.

\section{CONCLUSIONS}

1. The body build type of football players and basketball players was not different from that of non-training boys. Both athletes and non-training boys had slim figures, characteristic of the leptosomatic body build type.

2. In view of the sporadic lack of differences between football players and non-training boys, the analysed biometric features of the body build, i.e. body weight and height, should not be the only criterion for selection to play football, while in the case of basketball players a possibility of their use should be taken into consideration, with additional regard to the length of lower limbs. 


\section{REFERENCES}

[1] Kopczyńska-Sikorska J. O rozwoju dziecka w perspektywie auksologii [Child’s development from the viewpoint of auxology]. Kult Fiz. 2004;1-2:1-5. Polish.

[2] Malina RM. Anthropology and physical activity: A lifespan perspective. Med Sport. 2001;5:69-75.

[3] Wolański N. Rozwój biologiczny człowieka. Podstawy auksologii, gerontologii i promocji zdrowia [Biological development of man. Basics of auxology, gerontology and health promotion]. Warszawa: PWN; 2005. Polish.

[4] Wolański N. Metody kontroli i normy rozwoju dzieci i mlodzieży [Methods of control and development norms of children and youth]. Warszawa: PZWL; 1975. Polish.

[5] Łobocki M. Wprowadzenie do metodologii badań pedagogicznych [Introduction to the methodology of pedagogic research]. Kraków: Oficyna Wydawnicza Impuls; 1999. Polish.

[6] Malinowski A, Bożiłow W. Podstawy antropometrii. Metody, techniki, normy [Basics of anthropometrics. Methods, techniques and norms]. Warszawa: PWN; 1997. Polish.

[7] Drozdowski Z. Antropologia sportowa [Sports anthropology]. Warszawa-Poznań; PWN; 1984.

[8] Dega W, Marciniak W. Badanie narzadu ruchu [Examination of the motor organ]. In: Marciniak W, Szulc A, editors. Wiktora Degi Ortopedia i rehabilitacja. [Wiktor Dega's orthopaedics and rehabilitation]. Volume I. Warszawa: PZWL; 2003, 39-70. Polish.

[9] Krysicki W, Bartos J, Dyczka W, Królikowska K, Wasilewski M. Rachunek prawdopodobieństwa i statystyka matematyczna w zadaniach. Cz. 1 [Probability calculus and mathematical statistics in practice problems. Part 1]. Warszawa: PWN; 2013. Polish.

[10] Bangsbo J. The physiology of soccer - with special reference to intense intermittent exercise. Acta Physiol Scand. 1994;619(Suppl):1-115.

[11] Carvalho HM, Coelho e Silva MJ, Figueiredo AJ, et. al. Predictors of maximal short-term power outputs in basketball players 14-16 years. Eur J Appl Physiol. 2011;111:789-796.

[12] Malina RM, Bouchard C, Bar-Or O. Growth, maturation and physical activity. 2nd ed. Champaign IL: Human Kinetics, 2004, 449.

[13] Bieć E, Kuczyński M. Postural control in 13-year-old soccer players. Eur J Appl Physiol. 2010;110:703708.

[14] Całka-Lizis T, Jankowicz-Szymańska A, Adamczyk K. Postawa ciała uczniów regularnie trenujących piłkę nożną na tle rowieśników [Body posture in students who regularly train football vs. peers]. Med Sport. 2008;4(6):224-230. Polish.

[15] Grabara M. Analysis of body posture between young football players and their untrained peers. Hum Mov. 2012;13(2):120-126.

[16] Konieczna A. Budowa somatyczna a sprawność fizyczna piłkarzy nożnych w wieku okołopokwitaniowym. Rozprawa doktorska [Somatic build vs. fitness in football players at or around puberty. Doctoral dissertation]. Gdańsk: AWFiS; 2013. Polish.

[17] Stępiński M, Zwierko T, Florkiewicz B, Dębicka J. The level of chosen motor abilities of 13 years old soccer players. J Hum Kinet. 2003;9:99-107.

[18] Cięszczyk P, Stępiński M. W jaki sposób proces doboru wstępnego do piłki nożnej różnicuje kandydatów na tle innych dyscyplin sportowych i osob nietrenujacych? [How the preliminary selection process for football differentiates candidates as compared to other sports and non-training people]. Antropomotoryka. 2007;17(37):83-94. Polish.

[19] Carvalho HM, Coelho e Silva MJ, Figueiredo AJ, et. al. Cross-validation and reliability of the line-drill test of anaerobic performance in basketball players 14-16 years. J Strength Cond Res. 2011;25(4):1113-1119.

[20] Litkowycz R, Zając A, Waśkiewicz Z. Zmienność ontogenetyczna predyspozycji morfologiczno-strukturalnych koszykarzy na różnych etapach szkolenia sportowego [Ontogenetic changeability of morpho-structural predispositions of basketball players at various stages of sports training]. Antropomotoryka. 2005;15(30):39-45. Polish.

[21] Hadžic R, Bjelica D, Popovic S. Comparative study of anthropometric measurement and body composition between elite basketball and volleyball players. Research in physical education, sport and health. 2012;1(1):103-108.

[22] Koley S, Singh J. Anthropometric and physiological characteristics on Indian interuniversity basketball players. J Phys Educ Sport. 2010;28(3):70-76.

[23] Popovic S, Akpinar S, Jakšic D, Matic R, Bjelica D. Comparative study of anthropometric measurement and body composition between elite soccer and basketball players. Int J Morphol. 2013;31(2):461-467.

[24] Czarny W, Czaja R, Przyszlak A, Przyszlak R, Ostrowski P. Budowa somatyczna dzieci i mlodzieży trenującej koszykówkę w województwie podkarpackim [Somatic build in basketball-training children and youth in the Subcarpathian voivodeship]. Przegląd Naukowy Kultury Fizycznej Uniwersytetu Rzeszowskiego. 2005; t.VIII,nr 1-2:48-53. Polish.

[25] Vamvakoudis E, Vrabas IS, Galazoulas C, Stefanidis P, Metaxas TI, Mandroukas K. Effects of basketball training on maximal oxygen uptake, muscle strength, and joint mobility in young basketball players. J Strength Cond Res. 2007;21(3):930-936.

[26] Gaurav V, Singh M, Singh S. Anthropometric characteristics, somatotyping and body composition of volleyball and basketball players. J Phys Educ Sport Management. 2010;1(3):28-32.

[27] Marinković D, Pavlović S. The differences in aerobic capacity of basketball players in different playing positions. Phys Educ Sport. 2013;11(1):73-80. 
[28] Ostojic SM, Magic S, Dikic N. Profiling in basketball: Physical and physiological characteristics of elite players. J Strength Cond Res. 2006;20(4):740-744.

[29] Viswanathan J, Chandrasekaran K. Optimizing position-wise anthropometric models for prediction of playing ability among elite Indian basketball players. Int J Sports Sci Eng. 2011;5(2):67-76.

[30] Gil SM, Gil J., Ruiz F, Irazusta A, Irazusta J. Physiological and anthropometric characteristics of young soccer players according to their playing position: relevance for the selection process. J Strength Cond Res. 2007;21(2):438-445.

[31] Kochański L. Sprawność ogólna młodych piłkarzy nożnych na tle reprezentacji województwa mazowieckiego U-16 [General fitness in young football players in comparison with the Masovian voivodeship representation U-16]. Zeszyty Naukowe WSKFiT. 2014;9:57-62. Polish.

[32] Karalejic M, Jakovljevic S, Macura M. Antropometric characteristic and technical skills of 12 and 14 year old basketball players. J Sport Med Phys Fit. 2011;51(1):103-110.

[33] Karpowicz K. Interrelation of selected factors determining the effectiveness of training in young basketball players. Hum Mov. 2006;7(2):130-146.

[34] Malina RM, Rożek K, Ignasiak Z, et. al. Growth and functional characteristics of male athletes 11-15 years of age. Hum Mov. 2006;12(2):180-187.

[35] Ignasiak M, Stupnicki R. Sprawność fizyczna uczniow o zróżnicowanej sylwetce [Fitness in students of different figures]. Zeszyty Naukowe WSKFiT. 2013;08:19-25. Polish.

[36] Januszewski J, Mleczko E. Wskaźnik wagowo-wzrostowy Queteleta II - BMI a sprawność fizyczna badana w konwencji zdrowia u chłopców z Małopolski [Quetelet II weight to height index - BMI vs, fitness in Malopolska boys health convention]. Antropomotoryka. 2007;17(37):51-66. Polish. 